\title{
EDUKASI PEMBUATAN DAN PENYEMPROTAN DESINFEKTAN PADA MASYARAKAT DI DESA SURUANG KECAMATAN CAMPALAGIAN KABUPATEN POLEWALI MANDAR
}

\author{
Musafira $^{1}$, Fardinah ${ }^{2}$, Laila Qadrini ${ }^{3}$, Meryta Febrilian Fatimah ${ }^{4}$, Septiawan Ardiputra $^{5}$, \\ Asrirawan $^{6}$ \\ ${ }^{1,4)}$ Prodi Matematika, FMIPA, Universitas Sulawesi Barat. \\ ${ }^{2,3,6)}$ Prodi Statistika, FMIPA, Universitas Sulawesi Barat. \\ ${ }^{5)}$ Prodi Ilmu Politik, FISIP, Universitas Sulawesi Barat. \\ e-mail : musafira@unsulbar.ac.id ${ }^{1}$, fardinah@unsulbar.ac.id ${ }^{2}$, laila.qadrini@ unsulbar.ac.id ${ }^{3}$, \\ merytaff@unsulbar.ac.id ${ }^{4}$, septiawan.ardiputra@unsulbar.ac.id ${ }^{5}$, asrirawan@ unsulbar.ac.id ${ }^{6}$
}

\begin{abstract}
Abstrak
Salah satu upaya untuk menjaga lingkungan tetap bersih, sehat, dan bebas dari paparan virus corona adalah dengan melakukan penyemprotan cairan desinfektan. Pemerintah senantiasa menghimbau masyarakat agar dapat membuat desinfektan secara mandiri di rumah. Akan tetapi, masyarakat di Desa Suruang, Kecamatan Campalagian, Kabupaten Polewali Mandar masih banyak yang belum mengetahui cara membuat desinfektan, kalaupun masyarakat ada yang tahu membuat desinfektan pada umumnya mereka hanya sekedar mencampur bahan kimia tanpa mengetahui kandungan senyawa di dalam botol kemasan, bagaimana sifat senyawa tersebut dan bagaimana takaran tepatnya. Akibatnya, pencampuran bahan kimia tersebut justru dapat berdampak negatif bagi mereka seperti pembentukan senyawa baru yang berbahaya bagi kesehatan mereka. Olehnya itu, kegiatan dalam wujud edukasi tentang pembuatan desinfektan sangat perlu dilakukan.
\end{abstract}

Kata Kunci: Desinfektan, Corona, Desa Suruang, Kabupaten Polewali Mandar

\begin{abstract}
One of the efforts to keep the environment clean, healthy, and free from exposure to the corona virus is by spraying disinfectant liquid. The government always urges people to make disinfectants independently at home. However, many people in Suruang Village, Camplagian District, Polewali Mandar Regency, still do not know how to make disinfectants, even if people know how to make disinfectants in general, they just mix chemicals without knowing the content of the compounds in the bottle, what are the properties of these compounds. and how to measure it exactly. As a result, mixing these chemicals can actually have a negative impact on them, such as the formation of new compounds that are harmful to their health. Therefore, activities in the form of education about making disinfectants are very necessary.
\end{abstract}

Keywords: Disinfectant, Corona, Suruang Village, Polewali Mandar Regency

\section{PENDAHULUAN}

Sejak diumumkannya kasus pertama virus corona di Indonesia oleh presiden Joko widodo pada awal maret 2020, berbagai upaya dilakukan oleh pemerintah untuk mencegah penyebaran virus tersebut. Jumlah kasus pasien positif virus Corona semakin meningkat setiap hari, begitu juga dengan angka kematiannya. Sumber data dari (COVID \& Team, 2020), Indonesia pun mulai terpapar oleh Covid-19 dan per tanggal 17 Maret 2020 sebanyak 172 orang terinfeksi dengan 55 orang jumlah kematian. Perkembangan selanjutnya yakni 31 Maret 2020, kasus corona virus terjadi peningkatan diangka 1.528 orang dengan 136 orang jumlah kematian (Setiati \& Azwar, 2020). Peningkatan jumlah kasus yang cukup signifikan tersebut perlu dikendalikan bahkan harus dikurangi. Menurut C.Beiu et al dalam (Ardiputra et al., 2020) Upaya preventif terkait peningkatan jumlah penderita Covid-19, sebagaimana telah diinformasikan oleh WHO pada Maret 2020, bahwa untuk mencegah terjadinya penularan corona maka semua Negara didesak agra melakukan upaya dan langkah efektif. Maka pencegahan penyakit jenis ini mesti dilakukan sedini 
mungkin sesuai dengan UU 6 Tahun 2018 tentang Kekarantinaan Kesehatan, dimana perlunya pematasan kegiatan sosial oleh masyarakat (Telaumbanua dalam (Ardiputra et al., 2020)). Berbagai upaya yang dilakukan oleh pemerintah untuk mencegah penyebaran virus tersebut diantaranya adalah menghimbau masyarakat untuk tetap tenang, jaga jarak, kerja dari rumah (WFH), dan senantiasa menjaga kebersihan tubuh maupun lingkungan. Diantaranya yakni dengan kebiasaan mencuci tangan, menggunakan hand sanitizer, atau membersihkan dengan cairan disinfektan (Tribun Jatim, 2020). Sebelumnya, masyarakat antusias membuat hand sanitizer sendiri lantaran harganya naik drastis. Selain itu, salah satu formula yang bisa dibuat secara mandiri adalah disinfektan (Grid Fame.ID, 2020).

Senantiasa menjaga kebersihan lingkungan dan utamanya diri sendiri merupakan salah satu bentuk pencegahan penyebaran dan penularan Covid-19. Ada beberapa cara yang dapat dgunakan untuk mencegah penularan covid-19, salah satunya tidak bepergian ke daerah pandemi virus, menjalan kan PHBS, mencuci tangan setelah bepergian keluar rumah, menyemprotkan cairan desinfektan ke barang-barang yang beresiko menularkan virus (Marzuarman et al., 2020). Penggunaan Desinfektan dan Antiseptik dapat menjaga kebersihan diri dan lingkungan. Antiseptik mengandung anilides, chlorhexidine dan alkohol yang merupakan zat yang dapat menghambat perkembangan mikroorganisme tanpa harus membunuh mikroorganisme tersebut di jaringan hidup. Desinfektan merupakan zat yang dapat membunuh patogen di lingkungan. Glutaraldehid dan formaldehid merupakan zat yang terkandung dalam desinfektan. Sebelumnya tenaga medis merupakan pihak yang bertanggung jawab dalam hal penggunaan zat-zat tersebut di rumah sakit, namun saat ini, di rumah pun akan sering digunakan (Larasati \& Haribowo, 2020). Dari berbagai hasil penelitian yang telah dilakukan menunjukkan bahwa dalam penggunaan desinfektan dan antiseptik dapat membunuh virus secara efektif. Namun pembatasan jarak antara penderita dan pembawa mesti tetap dilakukan agar mencegah bertambahnya penularan. Dalam hal pengendalian laju persebaran Covid-19, perilaku individe, protokol kebersihan, pematasan jarak sosial dan isolasi mandiri merupakan sesuatu yang sangat penting untuk dilakukan (Larasati \& Haribowo, 2020). Salah satu langkah penting dalam upaya pencegahan dan penyebaran Covid-19 adalah dengan pembuatan cairan desinfektan. Antiseptik merupakan jenis disinfektan yang dapat menghancurkan atau bahkan menghambat perkembangan mikroorganisme tanpa mengakibatkan cidera pada jaringan hidup (Suryandari \& Haidarravy, 2020).

Salah satu upaya untuk menjaga lingkungan tetap bersih, sehat, dan bebas dari paparan virus corona adalah dengan melakukan penyemprotan cairan desinfektan (Kompas.com, 2020). Desinfektan adalah bahan kimia yang digunakan untuk membunuh mikroorganisme yang terdapat pada benda mati (Budiawan, 2012). Disinfektan adalah cairan pembersih yang umumnya dibuat dari hidrogen peroksida, creosote, atau alkohol yang bertujuan untuk membunuh bakteri, virus, kuman, dan mikroorganisme berbahaya lainnya yang terdapat pada ruangan atau permukaan benda mati. Disinfektan biasanya digunakan untuk membersihkan permukaan benda-benda yang paling sering disentuh orang banyak. Contohnya, gagang pintu, meja, kursi, keran wastafel, lemari, dan lain-lain. Disinfektan juga mengandung konsentrasi biosida yang tinggi. Maka dari itu, disinfektan lebih efektif dalam mencegah timbulnya bakteri dan mikroorganisme pada permukaan benda mati apa pun, yang menjadi perantara paparan infeksi virus atau bakteri berbahaya bila dihirup atau disentuh manusia (Manado, 2020). Untuk membuat disinfektan sendiri di rumah, sebenarnya kita bisa membeli bahan disinfektan utama yang merupakan produk pembersih rumah tangga. Jenis disinfektan yang direkomendasikan adalah cairan pemutih yang mengandung natrium hipoklorit atau cairan pembersih karbol yang mengandung benzalkonium klorida (Tribun Surabaya, 2020).

Upaya menjaga kebersihan lingkungan dengan penggunaan desinfektan bukan hanya tugas pemerintah saja, melainkan tugas semua masyarakat, tak terkecuali masyarakat yang ada di desadesa khususnya desa Suruang, Kabupaten Polewali Mandar. Olehnya itu, pemerintah senantiasa menghimbau masyarakat agar dapat membuat desinfektan secara mandiri di rumah. Akan tetapi, masyarakat di desa Suruang masih banyak yang belum mengetahui cara membuta desinfektan, kalaupun tahu membuat desinfektan pada umumnya mereka hanya sekedar mencampur bahan kimia tanpa mengetahui kandungan senyawa di dalam botol kemasan, bagaimana sifat senyawa tersebut dan bagaimana takaran tepatnya. Akibatnya, pencampuran bahan kimia tersebut justru dapat berdampak negative bagi mereka seperti pembentukan senyawa baru yang berbahaya bagi kesehatan mereka (Suara.com,2020). Olehnya itu, kegiatan dalam wujud edukasi tentang 
pembuatan desinfektan sangat perlu dilakukan. Berisi deskripsi tentang analisis situasi atau kondisi obyektif subyek pengabdian (komunitas dampingan), isu dan fokus pengabdian, alasan memilih subyek pengabdian, dan perubahan sosial yang diharapkan atau tujuan pengabdian masyarakat yang didukung dengan data-data kualitatif mapun kuantitatif, serta didukung dengan literature review yang relevan. Setidaknya, ada lima hal utama yang harus diperhatikan agar tetap aman untuk digunakan: 1. Selalu cek kandungan cairan pemutih Pada cairan pemutih atau sodium hipoklorit pada umumnya memiliki kandungan konsentrasi antara 2,5-5 persen. 2. Jangan gunakan air panas Saat melakukan pencampuran antara air dengan cairan pemutih pakaian tadi, jangan mencoba-coba dengan air panas. Jika dicampur dengan air panas, akan mengurangi khasiat dari sodium hipoklorit tersebut. 3. Buat sesuai takaran Takaran yang dianjurkan yakni 0.05 persen. Pengenceran terhadap sodium hipoklorit 5 persen dilakukan dengan perbandingan 1:100. Contohnya, 1 bagian bahan pemutih untuk 99 bagian air. Untuk mencapai konsentrasi sodium hipoklorit, perbandingan bahan pemutih dan air harus sesuai. 4. Waktu kontak harus diperhatikan Dianjurkan waktu kontak tidak lebih dari 10 menit ketika menggunakan cairan disinfektan untuk menggosok permukaan tak berpori. Selain itu, proses disinfeksi dengan merendam peralatan dianjurkan waktu kontak tak lebih dari 30 menit. 5. Bersihkan dari bahan-bahan organik Sebelum menggunakan disinfektan, permukaan yang akan dibersihkan juga harus dibersihkan dari pengotor bahan-bahan organik seperti lendir, muntah, feses, darah atau cairan tubuh lain (Kompas, 2020). Dengan bahan-bahan tersebut, cairan disinfektan buatan rumah dapat disemprotkan dua kali dalam sehari ke tempat-tempat yang berpotensi dihinggapi bakteri dan virus (Kumparan, 2020).

\section{METODE}

Metode yang digunakan dalam pengabdian ini terdiri atas empat tahap. Tahap pertama, tim pelaksana melakukan survei ke Desa Suruang Kecamatan Campalagian untuk koordinasi dengan pihak desa terkait kegiatan apa saja yang belum dilakukan desa dalam upaya pencegahan Covid-19 serta untuk mengetahui kondisi terkini desa bringin. Tahap kedua, tim pelaksana mempersiapkan pembuatan media yang akan digunakan sebagai upaya pencegahan Covid-19. Persiapan tersebut meliputi pembuatan desinfektan, pembuatan poster himbauan Covid-19. Tahap ketiga, tim pelaksana melaksanakan kegiatan di Desa Suruang Kecamatan Campalagian seperti kegiatan pembuatan dan penyemprotan desinfektan. Penyemprotan disinfektan sendiri memiliki 3 tahap yaitu: 1. Perizinan kepada pihak desa untuk pelaksanaan pengabdian, 2. Penyuluhan pembuatan desinfektan pada beberapa warga dan Pelaksanaan penyemprotan Desinfektan. 3. Tahap Evaluasi, tim pengabdi melakukan diskusi dengan kepala desa terkait kegiatan yang telah dilakukan sebagai upaya pencegahan Covid-19 di Desa Suruang. Kepala desa dan warga memberikan kesan dan saran terhadap pelaksanaan kegiatan pengabdian ini. Adapun metode pendekatan yang ditawarkan untuk mendukung realisasi program adalah dengan menggunakan metode ceramah dan diskusi karena peserta kegiatan ini terbatas dan senantiasa menjaga jarak antara tim pengabdi dan masyarakat mitra.

Tabel 1 Rencana Kegiatan Pengabdian Masyarakat

\begin{tabular}{|l|l|c|}
\hline Uraian Kegiatan & \multicolumn{1}{|c|}{ Tujuan } & Sasaran \\
\hline 1. Survey & $\begin{array}{l}\text { Memperoleh data terkait kondisi } \\
\text { masyarakat mitra }\end{array}$ & $\begin{array}{c}\text { Masyarakat lokal dan } \\
\text { pemerintah desa setempat }\end{array}$ \\
\hline 2. Penyuluhan & $\begin{array}{l}\text { Untuk memberikan informasi } \\
\text { terkait kegiatan pengabdian } \\
\text { yang akan dilaksanakan }\end{array}$ & Masyarakat lokal \\
\hline 3. Kerja Praktek & $\begin{array}{l}\text { Mengajarkan secara langsung } \\
\text { proses pembuatan desinfektan }\end{array}$ & Masyarakat lokal \\
\hline 4. Evaluasi & $\begin{array}{l}\text { Untuk mengetahui sejauh mana } \\
\text { pemahaman masyarakat akan } \\
\text { pengetahuan yang diberikan }\end{array}$ & $\begin{array}{c}\text { Masyarakat lokal dan } \\
\text { pemerintah desa setempat }\end{array}$ \\
\hline
\end{tabular}




\section{HASIL DAN PEMBAHASAN}

Tahap I: Perizinan kepada pihak desa

Persiapan dimulai sejak pengumuman proposal kegiatan ini disetujui untuk didanai yakni pada awal bulan September 2020. Persiapan dimulai dengan koordinasi dan konsolidasi tim dengan pihak LPPM UNSULBAR, penyiapan alat dan bahan, serta komunikasi dengan mitra kegiatan dan pihak terkait.

Hasil Survei Lokasi dan Sosialisasi dengan Mitra Kegiatan

Sesuai dengan proposal yang diajukan, kegiatan PKM ini dilakukan di desa Suruang yakni di Mesjid Nurul Hidayah dusun Buttu I kecamatan Campalagian kabupaten Polewali Mandar. Hasil survey diperoleh bahwa masyarakat pada umumnya belum mengetahui cara membuat desinfektan dengan baik dan benar. Disamping itu, pekerjaan warga dilokasi kegiatan adalah sebagian besar sebagai petani dan pedagang, sehingga tidak memiliki banyak waktu untuk mempelajari hal tersebut. Sosialisasi kegiatan dilakukan tanggal 18 September 2020 di rumah ketua pengurus mesjid Nurul Hidayah dusun Buttu I, sekaligus melakukan diskusi penetapan teknis pelaksanaan pelatihan.

Tahap II: Penyuluhan, Pelaksanaan, dan Peragaan

Pelatihan dilakukan pada tanggal 30 September 2020 di Mesjid Nurul Hidayah Dusun Buttu I Kecamatan Campalagian Kabupaten Polewali Mandar, yang meliputi:

1) Penyuluhan tentang bahan desinfektan yang aman bagi masyarakat.

2) Pengenalan alat dan bahan yang akan digunakan pada pembuatan desinfektan penjernihan air disertai dengan penjelasan setiap fungsinya

3) Peragaan pembuatan desinfektan.

4) Penyemprotan desinfektan di mesjid Nurul Hidayah

Hasil dari pelatihan yang dilakukan di lokasi, diperoleh bahwa masyarakat yang hadir di kegiatan ini dapat memahami materi singkat yang kami berikan dan menerima dengan baik informasi/pengetahuan yang kami berikan (Gambar 1). Disamping itu, selama kegiatan pengabdian ini terlihat respon positif dari masyarakat, dimana mereka ikut mengambil bagian dalam membersihkan mesjid (Gambar 2).

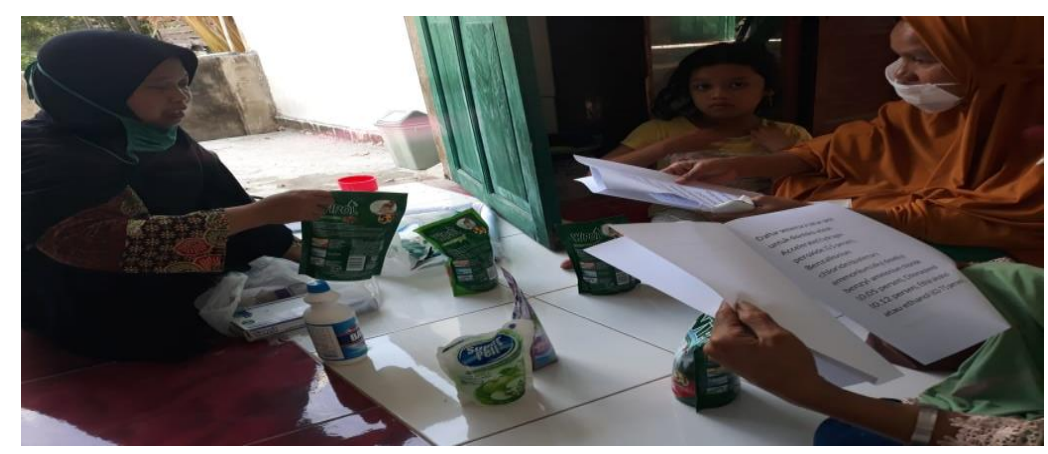

Gambar 1

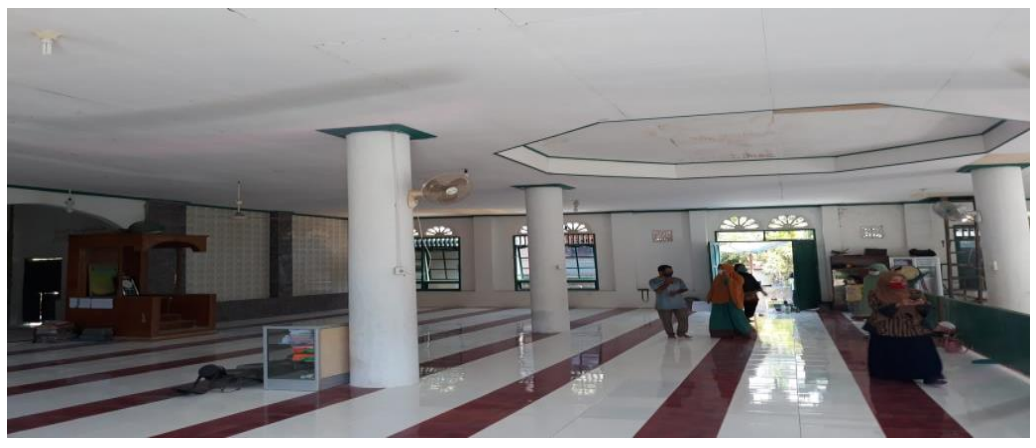

Adapun alat dan bahan yang digunakan pada pengabdian ini adalah:

Alat dan Bahan, Cairan Pemutih, Cairan Pembersih lantai, Semprotan, Pel Lantai dan Sapu, Air bersih secukupnya. Adapun cara Pembuatan Desinfektan yaitu Bahan cairan pemutih untuk 
membuat cairan disinfektan dengan pemutih pakaian (sodium hipoklorit), yang dibutuhkan sebagai campurannya hanya air. Pemutih pakaian tersebut dapat dilarutkan dengan air biasa dengan perbandingan 1:100. "Anjuran dari WHO seperti berikut, pengenceran 5 persen sodium hipoklorit dengan perbandingan 1:100 biasa dianjurkan. Gunakan 1 bagian bahan pemutih untuk 99 bagian air ledeng dingin (pengenceran 1:100) untuk disinfeksi permukaan”. Masyarakat perlu memperhatikan takaran antara cairan pemutih dan air seperti disebutkan di atas. Untuk konsentrasi cairan pemutih, sebisa mungkin tidak terlalu tinggi. Bahan cairan pembersih lantai memiliki bahan aktif yang lebih rendah dari cairan pemutih. Dengan demikian, dalam membuat disinfektan dari cairan pembersih lantai ini, dianjurkan perbandingannya tidak jauh berbeda antara cairan pembersih dan air. Takarannya, 10 tutup botol cairan pembersih lantai diencerkan dengan 1 liter air. Selain itu, dapat pula ditambahkan bahan pewangi alami, misalnya air hasil rebusan sereh untuk menetralkan bau karbol yang kadang menyengat. Namun, hal itu bisa disesuaikan dengan pilihan masyarakat.

\section{Tahap III: Evaluasi Kegiatan Pengabdian}

Tujuan dari diskusi dengan kepala desa Suruang sebagai standar keberhasilan tercapainya kegiatan pengabdian masyarakat sehingga nantinya bisa menjadi pedoman untuk kegiatan pengabdian lain yang serupa. Untuk meningkatkan potensi keberhasilan dari kegiatan pengabdian masyarakat ini dibutuhkan faktor-faktor pendukung. Faktor pendukung yang pertama, kontribusi kepala desa dan warga desa Suruang dalam membantu merealisasikan program kegiatan. Faktor pendukung kedua yaitu terwujudnya kerjasama antara seluruh anggota kelompok pengabdian masyarakat dalam menjalankan kegiatan yang dilakukan mulai dari survei lokasi dan koordinasi dengan kepala desa, pembuatan media dalam pelaksanaan kegiatan hingga pelaporan hasil kegiatan pengabdian masyarakat.

\section{SIMPULAN}

Dari hasil pelaksanaan kegiatan pengabdian dapat diambil kesimpulan bahwa masyarakat memberikan respon yang positif terhadap kegiatan ini dan berharap dapat membuat desinfektan dengan benar secara mandiri.

\section{UCAPAN TERIMA KASIH}

Kami selaku tim pengabdi, mengucapkan banyak terima kasih kepada Kepala Desa Suruang, Ketua Pengurus Masjid Nurul Hidayah Desa Suruang, serta para masyarakat Desa Suruang Kecamatan Campalagian Kabupaten Polewali Mandar baik secara langsung maupun tidak langsung yang telah sangat baik menyambut kami dan turut menyukseskan kegiatan pengabdian kepada masyarakat kami.

\section{DAFTAR PUSTAKA}

Ardiputra, S., Prawira, M. R., M.Tasbir, Permata, S. U., Listiawati, N., \& Qadrini, L. (2020). Pembagian Masker Dan Sosialisasi Kebijakan Pemerintah Dalam Rangka Mendukung Pencegahan Penyebaran Covid-19 Pada Masyarakat Desa Pallis Kecamatan Balanipa. Community Development Journal : Jurnal Pengabdian Masyarakat, 1 No.3, 395-400. https://doi.org/https://doi.org/10.31004/cdj.v1i3.1095

Budiawan, N. C. (2012). Penurunan Angka Kuman Dinding Ruang Perawatan di Balai Pengobatan Penyakit Paru-Paru (bp4) Kotagede setelah di desinfeksi menggunakan desinfektan " $v$." Poltekkes Kemenkes Yogyakarta.

COVID, T. C. D. C., \& Team, R. (2020). Severe Outcomes Among Patients with Coronavirus Disease 2019 (COVID-19)-United States, February 12-March 16, 2020. MMWR Morb Mortal Wkly Rep, 69(12), 343-346.

Grid Fame.ID. (2020). Grid Fame.ID. https://fame.grid.id/read/462080491/tak-hanya-dari-wipollarutan-disinfektan-juga-bisa-dibuat-menggunakan-bahan-bahan-yang-ada-di-kamarmandi?page $=$ all

Kompas.com. (2020). Kompas.com. https://www.kompas.com/tren/read/2020/03/30/054700165/membuat-disinfektan-sendiri-cara-bahan-dan-hal-yang-harus-diperhatikan?page=all

Kompas. (2020). Kompas. https://www.kompas.com/tren/read/2020/03/30/054700165/membuat- 
disinfektan-sendiri--cara-bahan-dan-hal-yang-harus-diperhatikan?page=all

Kumparan. (2020). Kumparan. https://kumparan.com/berita-hari-ini/cara-membuat-disinfektandengan-wipol-di-rumah-1t7lbQ5q5G4/full

Larasati, A. L., \& Haribowo, C. (2020). Penggunaan Desinfektan dan Antiseptik Pada Pencegahan Penularan Covid-19 di Masyarakat. Majalah Farmasetika, 5(3), 137-145.

Manado, T. N. (2020). Tribun News Manado. https://manado.tribunnews.com/2020/03/28/caramudah-membuat-desinfektan-menggunakan-cairan-karbol-air-bisa-di-coba?page $=4$

Marzuarman, M., Hadi, A., \& Lianda, J. (2020). Bilik Disinfektan Berbasis Ozon (Tanpa Cairan Kimia) Sebagai Upaya Pencegahan Penularan Covid-19 Di Lingkungan Upt Puskesmas Desa Pematang Duku Bengkalis. TANJAK, 1(1).

Setiati, S., \& Azwar, M. K. (2020). COVID-19 and Indonesia. Acta Medica Indonesiana, 52(1), 84-89.

Suara.com. (2020). Suara.com. https://www.suara.com/health/2020/04/02/070000/perhatikanjangan-pernah-mencampur-bahan-pembersih-ini-sebagai-disinfektan?page=all

Suryandari, N., \& Haidarravy, S. (2020). Pembuatan Cairan Desinfektan dan Bilik Disinfektan sebagai Upaya Pencegahan Virus Covid 19 di Majalah Bangkalan Madura. Jurnal Abdidas, $1(5), 345-351$.

Tribun Jatim. (2020). Tribun Jatim. https://jatim.tribunnews.com/2020/03/29/cara-membuatdisinfektan-pembunuh-virus-corona-dari-wipol-bayclin-17-produk-lain-simak-rumusnya

Tribun Surabaya. (2020). Tribun Surabaya. https://surabaya.tribunnews.com/2020/03/29/caramembuat-desinfektan-sendiri-menurut-anjuran-who-jangan-asal-bikin-perhatikan-3-halini?page $=3$ 